\title{
Entrepreneurs are Built, Not Born
}

\author{
Ron Mitchell (Texas Tech University)
}

KEYWORDS: Entrepreneurship.

\section{INTRODUCTION}

The question of whether entrepreneurs are born or made is age-old; and it strikes at the heart of economic development questions worldwide. In an increasingly global economy, entrepreneurs play a vital role in economic development, because they create organizations, and these organizations produce jobs, increase trade, and accelerate the generation, application of innovative ideas, and their dissemination (Arzeni, 1998: 18; Bates \& Dunham, 1993; McDougall \& Oviatt, 1997: 293). On one side of the debate is "characteristics-based" (the born-view) research, which asserts that entrepreneurs posess different innate attributes than do non-entrepreneurs. On the other side of the debate is research that is grounded in social cognition (the made-view), which asserts that differences in entrepreneurs' attributes can be explained by differences in their way of thinking or expertise. This article briefly summarizes research in both streams, with an emphasis upon an explanation of the relatively newer cognition-based approach.

\section{THE CHARACTERISTICS RESEARCH STREAM}

Jean-Baptiste Say (circa 1810), was one of the first scholars to note the "qualities" or characteristics of the entrepreneur; and his work has been prominent in the entrepreneurship literature. Say suggests:

"In the course of such complex operations there are an abundance of obstacles to be surmounted, of anxieties to be repressed, of misfortunes to be repaired, and of expedients to be devised. Those who are not possessed of a combination of these necessary qualities, are unsuccessful in their undertakings; their concerns soon fall to the ground." (Say, 1964 (1847): 331).

Note within the foregoing quotation the appealing notion that there might be a combination of personal characteristics that applies to entrepreneurial success. This idea has been so appealing that an entire literature stream has developed around it. Some of the first suggestions were theoretical speculations (Knight, 1921; Marshall, 1964). These were followed by descriptive studies (Berlew, 1975; Coulton \& Udell, 1976; McClelland, 1965). Then, somewhat recently (in the past few decades) rigorous analysis was conducted (Brockhaus, 1980; Brockhaus \& Nord, 1979; Hull, Bosley, \& Udell, 1982).

Advances in the research infrastructure then enabled characteristics-based theories of the entrepreneur to be more rigorously explored, primarily due to the inauguration of social science research in the nineteenth century, and particularly the beginnings of social psychology research methods in the twentieth century. These advances enabled researchers to explore the causal links between entrepreneurs' characteristics (psychological and/or demographic) and a variety of outcomes (cf. Sexton \& Bowman-Upton, 1991). However, empirical results in this explanation have lacked clarity (Brockhaus \& Horowitz, 1986; Sexton \& Bowman-Upton, 1991) despite the production within this literature stream of a substantial body of descriptive research.

The characteristics-based literature stream consists of two primary branches. The first branch bases entrepreneurs' distinctiveness based on their having unique psychological characteristics. The second branch bases such distinctions on entrepreneurs having unique demographic characteristics. The following paragraphs summarize several representative studies with applicable disconfirming results from each of two branches (psychological and demographic). It should be noted that this research stream has not continued to be prominent in the entrepreneurship literature due to confounding results; and therefore this summary is - of necessity - constrained to the citation of the research that is germane to the question.

\section{Examining the psychological characteristics of entrepreneurs}

A somewhat broad range of psychological characteristics has been the basis for psychological characteristics- 
based research focusing on entrepreneurs. The list of psychological characteristics examined includes (not exhaustively): needing to control and direct, having selfconfidence, possessing a sense of urgency, enjoying good health, having comprehensive awareness, applying down-to-earth realism, using superior conceptual ability, needing status, having objectivity in interpersonal relations, possessing emotional stability, having an attraction to challenge, using high levels of creativity, having a high need for achievement, believing that individual action can exert control over the environment (i.e., an internal locus of control), exhibiting a high risk-taking propensity, along with several others (Coulton \& Udell, 1976; McClelland, 1965; McClelland \& Winter, 1969; Rotter, 1966; Welsh \& White, 1981). In fact, using cluster and factor analysis, over 18,000 psychological trait terms (Allport \& Odbert, 1936) were reduced to 16 basic traits (Cattell, 1947) to form a foundation for much of the psychological characteristicsbased research (Herron, 1990: 51).

In this paper I provide only a few examples of disconfirming research concerning some of the most commonly cited psychological traits of entrepreneurs: need for achievement, belief that individual action can control the environment (i.e., an internal locus of control), and possessing a propensity for taking risks (Sexton \& Bowman-Upton, 1991) to illuminate, somewhat, the confusion within this research stream. Primarily, because the factors that describe entrepreneurs " . . . also tend to describe successful people in many areas, such as business, art, music, and education" (1991: 9), the "born entrepreneur" explanations are falsifiable. Below I explain some of these unclear areas.

Need for achievement. Scholars such as McClelland (1965) argue that a need for achievement propels individuals to become entrepreneurs. Yet research continues to demonstrate that although entrepreneurs may be high achievers, the same need for achievement has been identified in successful executives (Brockhaus \& Horowitz, 1986).

Internal locus of control. Continuing Rotter's (1966) work, Berlew (1975) has asserted that successful entrepreneurs are very willing to take personal responsibility for results, suggesting that entrepreneurs tend toward internal vs. external control in explaining their actions (have an internal locus of control). Brockhaus and Nord (1979) then compared the locus of control beliefs in entrepreneurs and managers, and found that entrepreneurs' level of internal locus of control does not differ significantly from that of managers. Hull, Bosley and Udell (1982) intended to distinguish between the personalities of entrepreneurs and non-entrepreneurs using a survey of over 300 University of Oregon alumni, and found that the one factor showing no significant difference is internal locus of control.

Risk-taking propensity. Coulton \& Udell (1976) also have reported that one of the psychological characteristics most important personality-typing entrepreneurs is risk-taking propensity. However when this report was tested using the patterns of risk preference of entrepreneurs vs. managers, Brockhaus (1980) found differences between the two groups to be nonsignificant. Additionally, Sexton and Bowman (1983) when testing the risk-taking distinction between entrepreneurs and others found no significant difference between the risk-taking propensity of entrepreneur students and the risk-taking propensity of the general student body (Sexton \& Bowman-Upton, 1983).

\section{Demographic characteristics}

Research exploring the possible association between individuals' demographic characteristics and a decision to be an entrepreneur, has been termed demographic characteristics-based research; and in the following paragraphs I provide a few examples to suggest that credibility in this branch of characteristics-based research also is problematic. Demographics tested in past research include variables such as: age, being the oldest child or the child of an entrepreneur, evaluation of personal shortcomings, membership in professional and/or trade organizations, number of anticipated difficulties, number of previous attempts to start a business, number of previous jobs, outside encouragement, profit expectations, years in the labor force, years of formal education, years of marriage, (Brockhaus \& Horowitz, 1986). However, empirical findings are mixed.

Some of the examples of disconfirming research on two of the most commonly cited demographic characteristics -- the child of an owner-manager, and education level (Litvak \& Maule, 1971; Vesper, 1982) -demonstrate a lack of clear empirical evidence in demographics-based explanations for becoming an entrepreneur.

Child of an owner-manager. In 1971, Litvak and 
Maule found that successful high-technology entrepreneurs had fathers who are owner-manager/ entrepreneurs, suggesting a familial/ hereditary demographic explanation. However, when Brockhaus and Nord (1979) empirically examined a sample of managers and new entrepreneurs to ascertain the extent to which a relative or a close friend had in the past owned a business, no significant difference was found between the groups.

Level of education. Vesper (1982) has asserted that entrepreneurs most likely to fail are individuals who have experience but no education, suggesting another likely demographically-based explanation for entrepreneurial success. However, previously Brockhaus and Nord (1979) find that education level for successful entrepreneurs is significantly less than for managers, and thereby raise questions about better understanding in general what might be an appropriate level of education. Subsequently, Brockhaus \& Horowitz then argued that "... one of the major concerns of those interested in innovation and continued growth of new business is the issue of whether entrepreneurs are born or whether they can be created through training" (1986: 37). At present this issue remains unresolved, although there are strong reasons to suggest that a cognitionbased approach (to be discussed next) may hold promise.

\section{Summary}

The characteristics-based approach to research concerning the question of "born vs. made" studies entrepreneurial characteristic based on psychology and demographics. The research objective has been to discover which individual characteristics in these two categories might be causal factors in entrepreneurial activity (Sexton \& Bowman-Upton, 1991). The resulting research has generally been of a descriptive nature, and has been inconclusive (Brockhaus \& Horowitz, 1986; Sexton \& Bowman-Upton, 1991). Enter the cognition research stream as a possible path toward better explanation.

\section{THE COGNITION RESEARCH STREAM}

The cognition research stream that has become the basis of entrepreneurial cognition research (see Randolph Seng, et al. 2015, for a review), began with social cognition theory which itself originally emerged to explain how individual behavior is shaped by interactions between people and the environment within which they live and act. The core assumption of social cognition theory is that individuals exist within some total situation, what might be termed a configuration of forces that relates two pairs of factors: the first pair of factors being cognition and motivation, and the second pair of factors being the person in that person's situation (emphasis in original) (Fiske \& Taylor, 1984: 4-5; Lewin, 1951). Social cognition theory requires that models used to explain individual behavior must approximate comprehensive reality (that is, cognition and motivation; and the person-in-situation) as perceived by the individual, when information about these two factor pairs is processed (Fiske \& Taylor, 1984: 5,16$)$. This requirement is reasonable, given that social cognition theory must account for the decision making behavior of individuals who might differentially perceive a given situation, especially due to differences in their information processing approaches. Hence, individual information processing thought to connect individual decision making to the elements to be found within a "total" situation. Salancik \& Pfeffer (1978) have suggested the social information processing perspective to explain individual decision-making such as making a venture creation decision; and it is this extension which further suggests the use of information processing theory to explain new venture creation.

In information processing theory there is a proffered explanation about how information is acquired, stored, and retrieved from individuals' memory. Lord \& Maher (1990) characterized at least five general models of information processing, each of which provide implicit frameworks for research. Of particular interest to me as I began entrepreneurship research was one of these models - the expert model-because of its capability to separate entrepreneurial experts from entrepreneurial novices (Mitchell, 1994). The expert model helps the researcher to identify commonalities among individuals in the group with expertise: generally those who are able to perform at least two standard deviations above the mean in a population (Ericsson, Krampe, \& TeschRomer, 1993); and based upon these commonalities, to identify the composition of new venture expertise (Mitchell, 1994), and in addition to empirically test these components for their explanatory capability in the classification and creation of new venture formation expertise (Mitchell \& Chesteen, 1995; Mitchell et al, 2000, 2002, 2008; Seawright et al, 2013; Smith et al, 2009). 
Using stable schema-based commonalities as one of the keys to unlock how entrepreneurs might be "made," were earlier found among experts in a variety of fields such as physics (Chi, Glaser, \& Rees, 1982), computer programming (McKeithen, Reitman, Reuter, \& Hirtle, 1981), chess playing (Chase \& Simon, 1972), and even law enforcement (Lurigio \& Carroll, 1985). Thus, because experts had been shown to possess knowledge structures or scripts about particular domains (Glaser, 1984; Leddo \& Abelson, 1986; Lord \& Maher, 1990; Read, 1987), it was highly appealing for me to construct research to ascertain the extent to which expert script might exist in entrepreneurship, and to identify their composition, and the resulting classification and entrepreneurial-thinking-creation capabilities (cf. Mitchell, 1994). For example, I have been able to show how the possession of an entrepreneurial expert script can distinguish experts from novices, because experts can use their readilyaccessible knowledge to make effective venture arrangements, to focus their motivation toward willingness to venture, and to apply their talents, or opportunity ability, to venturing (cf, Mitchell, 1994; Mitchell, et al, 2000, 2002).

Interestingly, in intention-based, planned behavior models of entrepreneurship decisions, (Krueger \& Carsrud, 1993; Shapero, 1975; Shapero, 1982) also suggest: (1) cognitions related to the feasibility of the venture (corresponding to arrangements), (2) cognitions related to the propensity to act (corresponding to willingness), and (3) cognitions related to venture desirability (corresponding to opportunity-ability-like cognitions) (Krueger, 1993: 5). Because information processing theorists Leddo \& Abelson (1986: 121), have explained how expert information processing theory generalizes these three processes for any type of expertise, and have termed them: arrangements cognitions, willingness cognitions, and ability cognitions, it was this terminology that I adopted in developing my work using expert-script based theory.

Of course, there are also problems that can arise for entrepreneur's cognition. Fortunately, the entrepreneurial cognition research literature has examined some of the consequences encountered by entrepreneurs when mental-process short-cuts (e.g., scripts) are used to cope with the entrepreneurial environment. The characteristics of entrepreneurial environments involve information overload, higher levels of uncertainty, impacts upon entrepreneurs' emotions, time pressures, adjustment pressures due to combinations of novel circumstances confronted while fatigued. McGrath (1999: 17-19) notes several thinking differences within the entrepreneurial context, among them: extrapolating the future from past success (e.g. oversampling success and under sampling failure), cognitive biases (e.g. confirmation bias which rejects disconfirming evidence), and even directly intervening to revise the cognitive situation (e.g. manipulation of metrics to show success regardless of actual results). Busenitz \& Barney (1997) examine overconfidence or representativeness errors; Simon, et al., (1999) explore overconfidence, illusion of control, and misguided belief in the law of small numbers.

Additionally, Mitchell \& Chesteen, (1995) examine venture expertise enhancement processes by extending into entrepreneurship, an expertise-based entrepreneurial-script enhancement methodology (Glaser, 1984; Petranek, Corey, \& Black, 1992) (cf., Table 1). Mitchell \& Chesteen (1995) argued that an individual can gain an expert script more-effectively through experiential learning that is expertise focused, by proceeding through a 9-step process in three phases (e.g. A 1-3; B 1-3; and C 1-3). The experiential activities included in the Table are: participating in experiences, writing about them, and then verbally debriefing these experiences with others who have also participated (e.g. interviewed a practicing entrepreneur). The cognitive enhancement occurs as each experiential activity is examined (interrogation), repeated (instantiation) and tested (falsification). This process is more fully explained below.

\section{Table 1}

\section{Experiential Enhancement Methodology}

\author{
Glaser (1984)
}




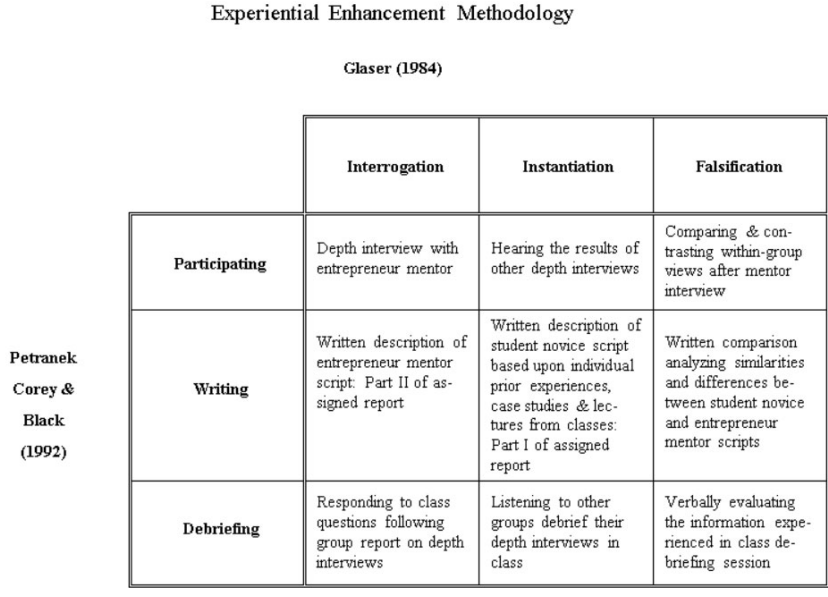

Source: Mitche11 \& Chesteen, 1995

Glaser (1984) argues for apprenticeship-like, one-onone experiences of novices with experts, that enable novice entrepreneurs to become more expert. Thus, in Row $A$, a learner first participates in an in-depth interview with an expert (e.g. a practicing entrepreneur), second instantiates (repeats) the learning of others' interviews, and third, attempts to cross-check or falsify the information gleaned. Then in the next phase, Row B, the learner changes from "listening" to "writing"; and by changing the medium, gains expertise at a higher rate once again in the three interrogation, instantiation, and falsification steps. In the final phase, Row C, debriefing, the three steps are repeated again. In a quasiexperiment, Mitchell and Chesteen (1995) showed how the elements of entrepreneurial expertise were better acquired by learners using the foregoing enhancement method as compared to the more common business plan drafting approach. That is, the control group in this study -individuals whose assignment was to engage in the more traditional enhancement activity, the writing of a business plan-showed no significant change in entrepreneurial expertise.

\section{Summary}

Thus, the cognition-based approach focuses the study of entrepreneurs using entrepreneurial thinking as the key phenomenon under investigation. This approach has extended entrepreneurship research beyond the descriptive research of the characteristics-based approach; and the resulting inferential research, instead of being inconclusive (cf., Brockhaus \& Horowitz, 1986; Sexton \& Bowman-Upton, 1991), has instead been much more conclusive (e.g. see Randolph-Seng, et al, 2015 for a complete review). In some respects at least, this research - in pushing the limits of more static views of cognition (i.e., the limits of input-process-outputbased "boxologies") - has laid the foundations for the socially situated (dynamic) view of cognition, and of entrepreneurial cognition specifically (Mitchell, Randolph Seng \& Mitchell, 2011). Recent work, both theoretically and empirically, has further supported these assertions (see, for example, Mitchell, Mitchell, \&Randolph-Seng, 2014 for a series of articles that capture the movement toward the dynamic cognitive perspective.)

What does the foregoing literature review therefore tell us about the born v. made question?

\section{DISCUSSION}

First, we are disappointed in the hope that a simple explanation of "the born entrepreneur" will be forthcoming from the characteristic research stream. Second, the cognition stream continues to offer hope for robust explanations for both the high achievement and some of the more unusual entrepreneurial behaviors. Third, it is a likely hypothesis that the cognition-based explanation is not restricted to particular types of entrepreneurs (e.g. opportunity vs. necessity). That is, when one considers the role of a mental map; it is neither the source of the mental map (opportunity creation/ discovery by whatever means triggered) nor the results of the mental map (opportunity creation/ discovery by whatever means enacted) that is relevant. The idea is that it is the cognitions, once in existence, are explanatory. Thus, it is now possible to observe that in a variety of settings entrepreneurs have been shown to be made, not born (although it is important to note the deliberate practice stream of research suggests that practice (repetition) tolerance is a characteristic that supports expertise acquisition, as suggested by Baron \& Henry, 2006, 2010, and Mitchell, 1995).

\section{Implications}

The implications of cognitive explanations for pedagogy and practice are as follows.

To the first question -- what is further implied with respect to entrepreneurship pedagogy? -- results from the testing of cognitively-based models suggest applications within society. That is, if the venture creation decision is associated with particular cognitive scripts, and if it has been demonstrated these scripts may be reliably transferred, then a map for entrepreneurship training programs is also suggested. 
In previous work at the University of Victoria, my colleagues and I had the opportunity to enact such a model (Appendix 1; Mitchell, et al, 2005). It is based upon the foregoing research and upon research in expert performance that maps the link between expert cognitions and deliberate practice (Ericsson et al., 1993).

To the second question -- what is further implied in practice? -- many of the results that have implications for practice have now been popularized (e.g. Malcolm Gladwell's book : Outliers). Gladwell seeks to explain success also by departing from the "born" explanation and using a "made" explanation that focuses on culture, family, birthdate, generational factors, and idiosyncrasies in their experiences. But in my view, the common factor is intense, long-duration deliberate practice of crucial skills - exactly what the cognitionbased theory explanation asserts. Hence, entrepreneurship must be "practiced" so that the necessary cognitive maps are formed. This applies to those who wish to be entrepreneurs; but also to those who make policy that can influence the development of entrepreneurial cognitive maps within cities, counties, states and nations.

\section{Conclusion}

Are entrepreneurs born or made? Like bird watching, the characteristics stream has succeeded in establishing within the popular mind a kind of descriptive elitism (Aren't the birds great? I wish I could fly!). But more like flight training, the cognitive stream is in a step-by-step manner establishing the maps and practice methods that make venturing a possibility for the majority in society. (Besides, by definition, we can't do much about "born"-but as leaders with new maps, we can surely make a difference in "made.")

\section{REFERENCES}

Abelson, R. P. \& Black, J. B. 1986. Introduction. In J. A. Galambos, R. P. Abelson \& J. B. Black ( Eds.), Knowledge Structures: 1-18. Hillsdale, NJ: Lawrence Erlbaum Associates, Inc.

Agle, B. R., Mitchell, R. K., \& Sonnenfeld, J. A. 1999. Who matters to CEOs? An investigation of stakeholder attributes and salience, corporate performance, and CEO values. Academy of Management Journal Special Research Forum on Stakeholder Theory, 42(5):
507-525.

Allport, G. W. \& Odbert, H. S. 1936. Trait names: A psycho-lexical study. Psychological Monographs, 47(1): 171-211.

Arzeni, S. 1998. Entrepreneurship and job creation. The OECD Observer: Paris: 18-20.

Baron, R. A. 1998. Cognitive mechanisms in entrepreneurship: Why and when entrepreneurs think differently than other people. Journal of Business Venturing, 13: 275-294.

Baron, R.A., Henry, R.A. 2006. Why do some entrepreneurs achieve extraordinary success? Insights from basic research on exceptional performance. Frontiers of Entrepreneurship Research, 26(10): 3.

Baron, R.A., Henry, R.A. 2010. How entrepreneurs acquire the capacity to excel: Insights from research on expert performance. Strategic Entrepreneurship Journal, 4(1): 49-65.

Bates, T. \& Dunham, C. R. 1993. Asian-American success in self-employment. Economic Development Quarterly, 7(2): 199-214.

Berlew, D. 1975. The nature of entrepreneurs. Paper presented at Proceedings of Project ISEED (International Symposium on Entrepreneurship and Enterprise Development), Columbus, Ohio.

Berne, E. 1976. Beyond Games and Scripts. New York: Ballantine.

Brockhaus, R. H. 1980. Risk taking propensity of entrepreneurs. Academy of Management Journal, 23(3): 509-520.

Brockhaus, R. H. \& Nord, W. R. 1979. An exploration of factors affecting the entrepreneurial decision: Personal characteristics vs. environmental conditions. Proceedings: Academy of Management.

Brockhaus, R. H. S. \& Horowitz, P. S. 1986. The psychology of the entrepreneur. In D. Sexton \& R. Smilor (Eds.), The Art and Science of Entrepreneurship: 25-48. Cambridge, MA: Ballinger.

Busenitz, L. W. \& Barney, J. B. 1997. Differences between entrepreneurs and managers in large 
organizations: Biases and heuristics in strategic decision-making. Journal of Business Venturing, 12(1): 9-30.

Busenitz, L. W. \& Lau, C. M. 1996. A cross-cultural cognitive model of new venture creation. Entrepreneurship Theory and Practice, 20(4): 25-39.

Cattell, R. B. 1947. Confirmation and clarification of primary personality traits. Psychological Bulletin, 72: 401-421.

Chase, W. G. \& Simon, H. A. 1972. The mind's eye in chess. In W. G. Chase ( Ed.), Visual Information Processing: 215-281. New York: Academic Press.

Chi, M. T. H., Glaser, R., \& Rees, E. 1982. Expertise in problem solving. In R. J. Sternberg ( Ed.), Advances in the Psychology of Human Intelligence: 7-75. Hillsdale, $\mathrm{NJ}$ : Lawrence Erlbaum Associates, Inc.

Coulton, R. \& Udell, G. G. 1976. The national science foundation's innovation center--An experiment in training potential entrepreneurs and innovators. Journal of Small Business Management(April): 1-20.

Ericsson, K. A. \& Charness, N. 1994. Expert performance: Its structure and acquisition. American Psychologist, 49(8): 725-747.

Ericsson, K. A., Krampe, R. T., \& Tesch-Romer, C. 1993. The role of deliberate practice in the acquisition of expert performance. Psychological Review, 100(3): 363-406.

Fiske, S. T. \& Taylor, S. E. 1984. Social Cognition. Reading, MA: Addison-Wesley.

Galambos, J. A. 1986. Knowledge structures for common activities. In J. A. Galambos, R. P. Abelson \& J. B. Black ( Eds.), Knowledge Structures: 21-47. Hillsdale, NJ: Lawrence Erlbaum Associates, Inc.

Gladwell, M. 2008. Outliers: The story of success. Little, NY: Brown \& Co.

Glaser, R. 1984. Education and thinking. American Psychologist, 39: 93-104.

Goffman, E. 1959. The Presentation of Self in Everyday Life. Garden City, NY: Doubleday.

Herron, L. 1990. The Effects of Characteristics of the
Entrepreneur on New Venture Performance. Columbia, SC: University of South Carolina Press.

Hull, D., Bosley, J. J., \& Udell, G. G. 1982. Renewing the hunt for means of identifying potential entrepreneurs by personality characteristics. Journal of Small Business Management, 20(2): 11-19.

Knight, F. H. 1921. Risk, Uncertainty and Profit. New York: Kelley and Millman, Inc.

Krueger, N. 1993. The impact of prior entrepreneurial exposure on perceptions of new venture feasibility and desirability. Entrepreneurship Theory \& Practice, 18(1): 5-21.

Krueger, N. F. \& Carsrud, A. L. 1993. Entrepreneurial intentions: Applying the theory of planned behaviour. Entrepreneurship and Regional Development, 5: 315-330.

Leddo, J. \& Abelson, R. P. 1986. The nature of explanations. In J. A. Galambos, R. P. Abelson \& J. B. Black (Eds.), Knowledge Structures: 103-122. Hillsdale, NJ: Lawrence Erlbaum Associates, Inc.

Lewin, K. 1951. Field theory in social science. New York: Harper.

Litvak, I. A. \& Maule, C. J. 1971. Canadian entrepreneurship: A study of small newly established firms. Ottawa: Department of Industry, Trade and Commerce.

Lord, R. G. \& Maher, K. J. 1990. Alternative informationprocessing models and their implications for theory, research, and practice. Academy of Management Review, 15(1): 9-28.

Lurigio, A. J. \& Carroll, J. S. 1985. Probation officers' schemata of offenders: Content, development, and impact on treatment decisions. Journal of Personality and Social Psychology, 48: 1112-1126.

Marshall, A. 1964. Principles of Economics (9th ed.). London: Macmillan and Co.

McClelland, D. C. 1965. Need achievement and entrepreneurship: A longitudinal study. Journal of Personality and Social Psychology, 1: 389-392.

McClelland, D. C. \& Winter, D. G. 1969. Motivating 
Economic Achievement. New York: Free Press.

McDougall, P. P. \& Oviatt, B. M. 1997. International entrepreneurship literature in the 1990s and directions for future research. In D. L. Sexton \& R. W. Smilor ( Eds.), Entrepreneurship 2000: 291-320. Chicago, IL: Upstart Publishing.

McGrath, R. G. 1999. Falling forward: Real options reasoning and entrepreneurial failure. Academy of Management Review, 24(1): 13-30.

McKeithen, K. B., Reitman, J. S., Reuter, H. H., \& Hirtle, S. C. 1981. Knowledge organization and skill differences in computer programmers. Cognitive Psychology, 13: 307-325.

Mitchell, R. K. 1994. The composition, classification, and creation of new venture formation expertise. Management Department. Salt Lake City, UT: University of Utah.

Mitchell, R. K. 1995. The New Venture Template. Victoria, BC, Canada: Ronald K. Mitchell.

Mitchell, R. K. 1998. Entrepreneurship and security seeking in an imperfect economy. Working Paper, University of Victoria, Victoria, BC.

Mitchell, R. K., Agle, B. R., \& Wood, D. J. 1997. Toward a theory of stakeholder identification and salience: Defining the principle of who and what really counts. Academy of Management Review, 22(4): 853-886.

Mitchell, R. K. \& Chesteen, S. A. 1995. Enhancing entrepreneurial expertise: Experiential pedagogy and the entrepreneurial expert script. Simulation \& Gaming, 26(3): 288-306.

Mitchell, J. R., Mitchell, R. K., Randolph-Seng, B. 2014. Handbook of Entrepreneurial Cognition, Northampton MA: Edward Elgar.

Mitchell, R. K., Mitchell, J. R. Smith, J. B. 2008. Inside opportunity formation: Enterprise failure, cognition, and the creation of opportunities. Strategic Entrepreneurship Journal, 2: 225-242.

Mitchell, R. K., Randolph-Seng, B., Mitchell, J. R. 2011. Socially situated cognition: Imagining new opportunities for entrepreneurship research. Academy of Management Review - Dialogue: Vol. 36(4): 774-778.
Mitchell, J. R., Smith, J. B., Gustafsson, V., Davidsson, P., Mitchell, R. K. 2005. Thinking about thinking about thinking: Exploring how entrepreneurial metacognition affects entrepreneurial expertise. Presented June 10, 2005, Babson College, Wellesley, MA http://www.ronaldmitchell.org/publications/ttt.pdf.

Frontiers of Entrepreneurship Research: p. 36.

Mitchell, R. K., Smith, J. B, Morse, E. A., Seawright, K. W., Peredo, A-M, McKenzie, B. 2002. Are entrepreneurial cognitions universal? Assessing entrepreneurial cognitions across cultures. Entrepreneurship Theory \& Practice, 2002: 9-32.

Mitchell, R. K., Smith, J. B., Seawright, K. W., Morse, E. A. 2000. Cross-cultural cognitions and the venture creation decision. Academy of Management Journal, 43(5) October, 2000: 974-993.

Petranek, C. F., Corey, S., \& Black, R. 1992. Three levels of learning in simulations: Participating, debriefing, and journal writing. Simulation and Gaming, 23: 174-185.

Porter, M. E. 1980. Competitive Strategy: Techniques for Analysing Industries and Competitors. New York: Free Press.

Randolph-Seng, B., Mitchell, R. K., Vahidnia, H., J. R. Mitchell, Chen, S, Statzer, J. 2015. The microfoundations of entrepreneurial cognition research: Toward an integrative approach. Foundations \& Trends in Entrepreneurship Research, 11(4): 207-223.

Read, S. J. 1987. Constructing causal scenarios: A knowledge structure approach to causal reasoning. Journal of Personality and Social Psychology, 52: 288-302.

Rotter, J. B. 1966. Generalized expectations for internal versus external control of reinforcement. Psychological Monographs, 80(1): 1-28.

Rumelt, R. P. 1987. Theory, strategy, and entrepreneurship. In D. J. Teece ( Ed.), The Competitive Challenge: Strategies for Industrial Innovation and Renewal: 137-158. Cambridge, MA: Ballinger.

Salancik, G. R. \& Pfeffer, J. 1978. A social information approach to job attitudes and task design. Administrative Science Quarterly, 23: 224-253. 
Say, J. B. 1964 (1847). A Treatise on Political Economy. New York: Augustus M. Kelley.

Seawright, K. W., Smith, I., Mitchell, R. K., McClendon, R. J. 2013. Exploring entrepreneurial cognition in franchisees: A knowledge-structure approach. Entrepreneurship Theory \& Practice, March 2013, Vol. 37: 201-227.

Sexton, D. L. \& Bowman-Upton, N. 1983. Comparative entrepreneurships, characteristics of students. In J. A. Hornaday, J. Timmons \& K. H. Vesper ( Eds.), Frontiers of Entrepreneurship Research: 465-478. Wellesley, MA.: Babson Center for Entrepreneurial Studies.

Sexton, D. L. \& Bowman-Upton, N. 1991. Entrepreneurship: Creativity and Growth. New York: MacMillan Publishing Company.

Shapero, A. 1975. The displaced, uncomfortable entrepreneur. Psychology Today, 9(November): 83-88, 133.

Shapero, A. 1982. Social dimensions of entrepreneurship. In C. K. e. al. ( Ed.), The Encyclopedia of Entrepreneurship: 72-90. Englewood Cliffs, NJ: Prentice Hall.

Shoemaker, P. J. H. 1993. Multiple scenario development: Its conceptual and behavioral foundation. Strategic Management Journal, 14(3): 193-213.

Smith, J. B., Mitchell, J. R., Mitchell, R. K. 2009. Entrepreneurial scripts and the new transaction commitment mindset: Extending the expert information processing theory approach to entrepreneurial cognition research. Entrepreneurship Theory \& Practice, July 2009, Vol. 33-34: 815-844.

Stapleton, R. J. \& Murkison, G. 1990. Scripts and entrepreneurship. Transactional Analysis Journal, 20(3): 193-197.

Vesper, K. H. 1982. Introduction and summary of entrepreneurship research. In C. A. Kent, D. L. Sexton \& K. H. Vesper ( Eds.), Encyclopedia of Entrepreneurship: xxi-xxxviii. Englewood Cliffs, NJ.: Prentice-Hall.

Walsh, J. P. 1995. Managerial and organizational cognition: Notes from a trip down memory lane. Organization Science, 6(6): 280-321.
Welsh, J. A. \& White, J. F. 1981. Converging on characteristics of entrepreneurs. In K. H. Vesper \& e. al ( Eds.), Frontiers of Entrepreneurship Research: 504-515. Wellesley, MA.: Babson Center for Entrepreneurial Studies.

Williamson, O. E. 1985. The Economic Institutions of Capitalism. New York: The Free Press. 


\section{APPENDIX 1}

The University of Victoria Entrepreneurship Program is built upon a model of entrepreneurial expertise that is based upon research (Mitchell, 1994) that demonstrates that that new venture formation is related to cognitive expert scripts. This model utilizes the relationships among the individual (entrepreneur), the work (the venture) and others (the venture stakeholders), to derive the three areas of pedagogic concern in teaching entrepreneurship: building Planning (Arrangements), Promise (Willingness), and Competition (Opportunity Ability) expert scripts (Mitchell, 1998; Mitchell et al., 2000). The relationship among these three pedagogic elements is shown in the following diagram:

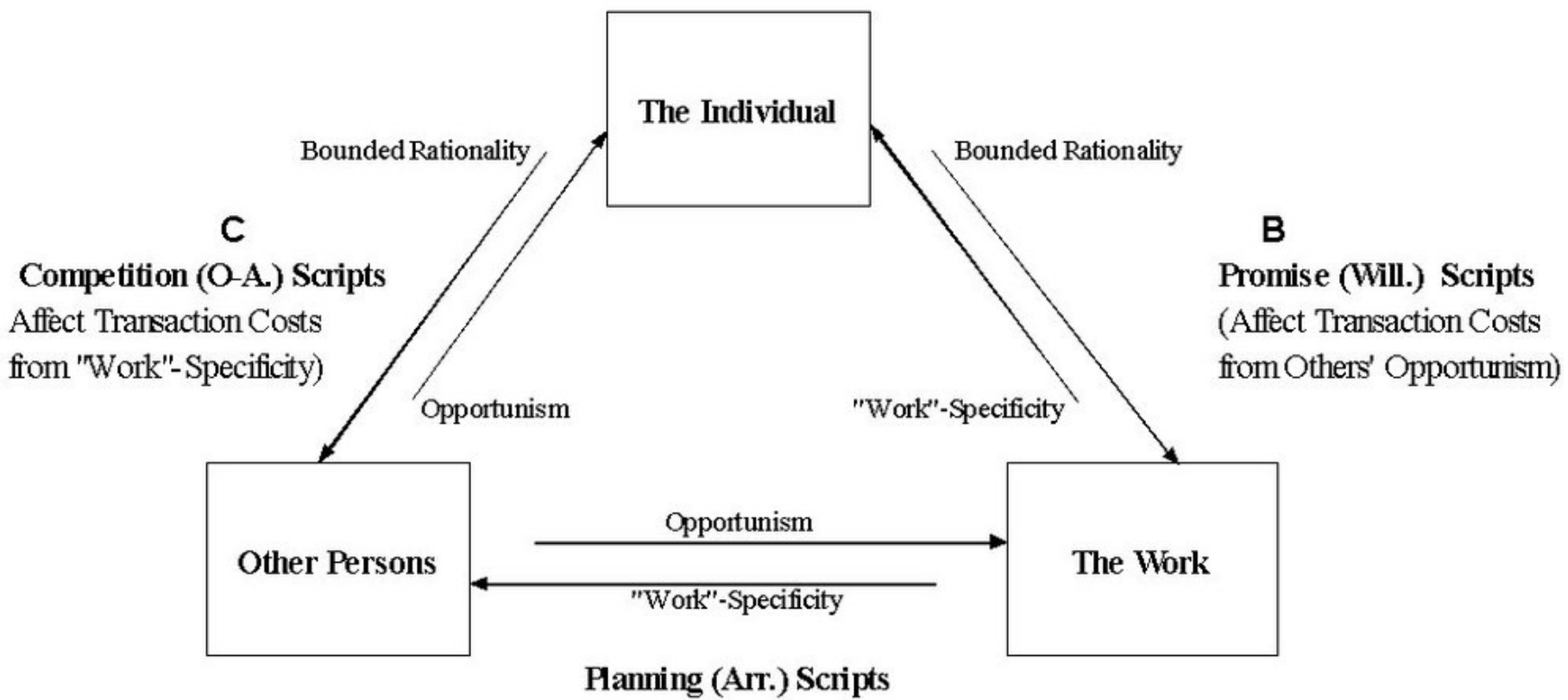

(Affect Transaction Costs from Individuals' Bounded Rationality)

Since the growth of a new firm is based on the success of the transactions of a company, then it logically follows that, if the transactions are successful, then the firm will have a sound foundation for success. The three sources of market imperfection (Rumelt, 1987; Williamson, 1985) that affect transaction success are:

1. Bounded rationality: Since the individual's information about the work and others is limited, so also is the ability to make perfect rational decisions limited (or bounded) by this incomplete information. Planning utilizes bounded rationality to turn this market imperfection into profits.

2. Opportunism: Since it is the nature of stakeholders to attend to their own best interests with guile, relationships with others that create viable promises, again utilize market imperfection to produce profit.

3. Specificity: Since the work in a venture is specific, scripts are needed that make this work competitive in the eyes of the market (the others).

The pedagogy of the University of Victoria Entrepreneurship Program is based on teaching the cognitive scripts (planning, promise, and competition) that permit individual entrepreneurs to organize exchange relationships (among the individual, other persons, with respect to the work) that utilize market imperfections (bounded rationality, opportunism, specificity) to create value.

1. Bounded Rationality: To best utilize market imperfections from bounded rationality we must improve the venturer's knowledge-specifically through enhancing planning capabilities. In particular, the venturer's knowledge of the venturing expert script must be increased. To increase this knowledge, we use the "script enhancement" method (Mitchell \& Chesteen, 1995) consisting of these steps: 
- Temporary script sequences provide the novice with a framework for this process, a starting point.

- Expert-novice communication of past experience helps the novice understand what norms have worked for experts and likely will work for the novice.

- Real experience enables the novice to develop his own norms and truly become an expert.

1. Opportunism: The management of opportunism through the creation of promise-based scripts is embedded in a stakeholder management approach. The goal of this approach is to identify and serve the stakeholders of a company (Agle, Mitchell, \& Sonnenfeld, 1999; Mitchell, Agle, \& Wood, 1997) by utilizing three stakeholder attributes:

- Power

- Legitimacy

- Urgency

The more characteristics a stakeholder has, the more salient it is to the company. Using this logic, the acquisition of promise scripts help of align the goals of the stakeholders (others) with that of the work and individual (based on their power, legitimacy and urgency) to utilize the market imperfections created by opportunism to build value within the venture.

1. Specificity: The effective use of the market imperfections that arise due to specificity comes about where entrepreneurs - through the use of effective competition scripts that, for example, affect the cost or differentiation the work (Porter, 1980) - produce sustainable value. To do this we use a tool such as the New Venture TemplateTM (NVT), (Mitchell, 1995) an expert assistance computer program that helps the prospective venturer to assess "if the venture is indeed a business" and "if it is sustainable." Using the NVT, we can determine how to increase the competitive stance of the venture work. 